\title{
The assessment of temperature amplitude arising during the implant bed formation in relation to variable preparation parameters - in vitro study
}

\author{
PIOTR KOSIOR ${ }^{1 *}$, ANNA NIKODEM ${ }^{2}$, MARTA KOZUN' $^{2}$, KRZYSZTOF DUDEK $^{3}$, \\ MACIEJ JANECZEK ${ }^{4}$, MACIEJ DOBRZYŃSKI $^{5 *}$ \\ ${ }^{1}$ Department of Conservative Dentistry with Endodontics, Wroclaw Medical University, Wrocław, Poland. \\ 2 Department of Mechanics, Materials and Biomedical Engineering, Faculty of Mechanical Engineering, \\ Wrocław University of Science and Technology, Wrocław, Poland. \\ ${ }^{3}$ Faculty of Mechanical Engineering, Wrocław University of Science and Technology, Wrocław, Poland. \\ ${ }^{4}$ Department of Biostructure and Animal Physiology, Wrocław University of Environmental and Life Sciences, Wrocław, Poland. \\ ${ }^{5}$ Department of Pediatric Dentistry and Preclinical Dentistry, Wrocław Medical University, Wrocław, Poland.
}

\begin{abstract}
The main purpose of this study was to analyse the temperatures generated during the bone bed preparation, given the internal structure of the bone bed, the geometry of the hole, and the treatment parameters such as the type of cooling and the rotational speed of the drill. The investigated material was domestic pig ribs, in which holes were drilled three times using two drill bit systems used for Hiossen $^{\circledR}$ and Paltop ${ }^{\mathbb{B}}$ dental implantation. The ThermaCAM ${ }^{\circledR}$ P640 thermal imaging camera was used for measurement of drilling temperatures. After the holes were drilled, each rib was examined using the 1172 SkyScan microtomograph, Bruker ${ }^{\circledR}$, to compare the geometry of the machined holes. The presented study proved that larger diameter drill bits (Hiossen ${ }^{\circledR}$ drill bits) generate more heat during the machining process, as evidenced by higher temperatures obtained for the Hiossen system in each case. It was proved that rotational speed, drill bit diameter and cooling system have a significant effect on the amount of heat generated during bone tissue preparation. The density and type of bone tissue in which the hole is prepared are significant factors affecting the amount of heat generated.
\end{abstract}

Key words: dental implants, thermal damage, bone, osseointegration, thermography, microtomography

\section{Introduction}

The preparation of holes in bone in both dental and orthopaedic surgery involves overcoming the resistance forces that the bone tissue exerts on the drill bit [11]. During the preparation, friction is generated between the bone tissue and the rigid element - a drill bit (which additionally becomes stiffer as rotational speed of the tool increases). On the other hand, there is also pressure made by the operator during the procedure. In hard tissues, friction must be overcome by significant tool pressure at the preparation site. The high pressure and friction between the drill bit and the bone tissue are the cause of the high temperature that affects both the drill bit and the surrounding tissues. The heat balance in the drilling process includes the frictional work of the drill point contact surface against the surface of the material under machining (10\% of heat generated), the frictional work of the tissue against the drill point contact surface $(20 \%$ of heat generated), as well as the elastic and plastic deformation work of the material layer $(70 \%$ of heat generated). The amount of generated heat is also proportionally affected by the depth of the drilled hole and the speed of the machining process. The generated temperature is affected not only by the heat generated in the drilling process, but also by its dissipa-

* Corresponding authors: Piotr Kosior, Department of Conservative Dentistry with Endodontics, Krakowska 26, 50-425, Wrocław, Poland. Phone: +48 717840366, e-mail: piotr.kosior@umw.edu.pl; Maciej Dobrzyński, Department of Pediatric Dentistry and Preclinical Dentistry, Krakowska 26, 50-425, Wrocław, Poland. Phone: +48 717840361, e-mail: maciej.dobrzynski@umw.edu.pl

Received: June 3rd, 2021

Accepted for publication: October 5th, 2021 
tion from the preparation zone. Approximately $75 \%$ of the heat is dissipated through the bone material produced during the machining process, the type and shape of which are determined by the properties of the tissue itself as well as the machining conditions and the geometry of the drill point. Other routes of heat dissipation include the tissue during preparation and the tool used during machining (25\%). Heat dissipation from the machining zone depends largely on the speed of the machining process. At low machining speeds for highspeed steel tools, much of the generated heat is transferred to the material under machining. As the drill bit speed increases, the transfer of heat into the material under machining becomes more difficult, thus a greater role in its reception is taken by the material that constantly leaves the preparation zone.

An increase in temperature during bone tissue drilling may lead to necrosis of the surrounding tissues, failure of osseointegration and a reduction in the longterm success of implantation. In terms of materials, biological tissues such as bone and dental tissues belong to the ceramic-polymer composites, where there is a proteinaceous polymer. Initially, the temperature threshold for thermal bone damage, which is an irreversible process, was estimated at $56{ }^{\circ} \mathrm{C}$. However, Eriksson and Albrektsson's [8] study conducted on rabbit bone tissue found that an increase in bone temperature as low as $50{ }^{\circ} \mathrm{C}$ or $46^{\circ} \mathrm{C}$, lasting longer than a minute, causes irreversible changes in bone tissues. Similar results were also obtained by Alwan [1], who proved that an increase in temperature during implantation causes the death of cells, peri-implant tissues and thermal denaturation of collagen in bone tissue. When collagen is denatured, free and structured water is released and the chain conformation is destabilised; due to thermal vibration, the chain changes into a disordered structure. The loss of water additionally affects the disruption of biological processes related to preadsorption in the process of implant and tissue osseointegration, so that in the FBR (fluidized bed reactor) process, the implant is surrounded by a fibrous capsule, which may lead to its destabilisation [9]. According to Sener et al. [25], Eriksson et al. [8] and Brisman [4], the effects of overheating on surrounding bone include necrosis, fibrosis, bone cystic degeneration, a general decrease in the osteoblastic activity. These effects are due to the physical characteristics of the bone itself, which has a very low thermal conductivity that prevents the heat dissipation while drilling.

The effects of factors such as function of drill bit design [5], [22], [23], [26], repeated utilisation of drill units [6] and irrigation method [3] on the heat values (temperature) generated in the machining process has been the subject of many scientific studies. According to Flangan [10] and Marković et al. [20], a reduction in the heat generated during bone tissue drilling and implant placement procedure can be achieved by increasing the drill bit diameter, decreasing the rotational speed of the drill bit during drilling or using bone condensing technique. In bone tissue (especially cancellous tissue) under drilling, the drill bit grooves that evacuate bone chips may become clogged. The result is an inaccurate hole, an increase in temperature in the preparation zone and, in extreme cases, the drill bit damage. There have been many studies concerning the impact of drilling process parameters (drill bit diameter, rotational speed) and the type of a cooling system used on the temperature generated during bone machining and thus cell necrosis. Kalidindi [15] obtained the highest temperatures for machining without a cooling system. Kirstein et al. [17], [18] found that the lack of a cooling system results in increased bone tissue damage (regardless of the machining speed used). According to Mecran et al. [20], the coolant volume that is necessary for the most effective cooling is $56 \mathrm{ml} / \mathrm{min}$. The authors also indicate that the temperature of the used coolant has a significant effect on reducing both thermal necrosis and its risk. Sener et al. [25] revealed that lower coolant temperature $\left(10^{\circ} \mathrm{C}\right)$ may reduce both the temperature generated during machining and the risk of thermal damage. Moreover, Nam et al. [21], Augustin et al. [2] and Kalidindi [15] observed that the higher the drill bit rotational speed, the higher the temperature obtained during machining. According to Kim et al. [16], the optimal rate that stimulates osseointegration and reduces thermal damage ranges from $1000 \mathrm{rpm}$ to $1500 \mathrm{rpm}$. The opposite results were presented by Sharawy et al. [24]. Namely, the authors obtained lower temperatures at higher rotational speeds.

The existing studies on the aforementioned subject provide information concerning the temperature generated during mechanical treatment of bone tissue and resulting thermal necrosis from the perspective of machining process parameters such as rotational speed, drill bit diameter, type of cooling system. No study has included the thickness of the cortical bone layer and the geometry of the drilled hole (diameter, length) in the analysis. These are factors that, combined with preparation process parameters, may also affect the heat generated during drilling in bone [5], [15]. This study aimed to analyse the temperature generated during bone bed preparation, given the internal structure of the bone bed, the geometry of the hole (diameter, length) and the treatment parameters. 


\section{Materials and methods}

\subsection{Experimental model}

The investigated material consisted of twelve domestic pig ribs of similar size, given the length, thickness and width (Fig. 1). It should be stressed that these models show different values of geometrical parameters [12], [14]. The average mean diameter of the ribs used in this study was $10.23 \pm 1.35 \mathrm{~mm}$, while the average thickness of the cortical bone tissue layer was $1.8 \pm 0.4 \mathrm{~mm}$. The ribs were obtained from a slaughterhouse. Each rib was drilled three times to use dental implants. Two types of implant systems were evaluated: Paltop $^{\mathbb{B}}$ (Burlington, MA, USA) and Hiossen ${ }^{\mathbb{B}}$ (Englewood Cliffs, NJ, USA). The diameter of the drill bits was a sequence dedicated to a given system. Drill bits with a diameter of $2.0 \mathrm{~mm}, 2.4 \mathrm{~mm}$ and $3.75 \mathrm{~mm}$ were used for the Paltop ${ }^{\circledR}$ system, while those with a diameter of $2.8 \mathrm{~mm}, 3.8 \mathrm{~mm}$ and $4.0 \mathrm{~mm}$ were used for the Hiossen ${ }^{\circledR}$ system. Both systems used drill bits with the same point angles $-120^{\circ}$ (Fig. 2).

The geometry of drill bits was assessed using the Discovery V20 stereo microscope, Zeiss ${ }^{\circledR}$.

For drilling, the NeoSurge implant engine (NEO BIOTECH, Saeshin United, Korea) was used with an auto-reverse option, equipped with a 32:1 contra-angle handpiece. Each hole was made three times. Firstly, an initial hole (with the smallest diameter) was drilled, which was then reamed twice to obtain the final diameter and shape of the hole. The holes were drilled using three different rotational speeds, i.e., $800 \mathrm{rpm}$, $1200 \mathrm{rpm}$ and $1500 \mathrm{rpm}$, and under different cooling conditions - without cooling (dry cooling), cooling using $0.9 \% \mathrm{NaCl}$ solution at $3{ }^{\circ} \mathrm{C}$ and cooling using $0.9 \% \mathrm{NaCl}$ solution at room temperature $\left(20^{\circ} \mathrm{C}\right)$. The thrust force was similar in all measurements. The pressure ranged from 0 to $720 \mathrm{~g}(750 \mathrm{~g} \pm 12 \mathrm{~g})$. The drilling method used in this study was based on previous studies that were published in detail in other articles [16], [17]. Temperature measurements were taken each time during machining.
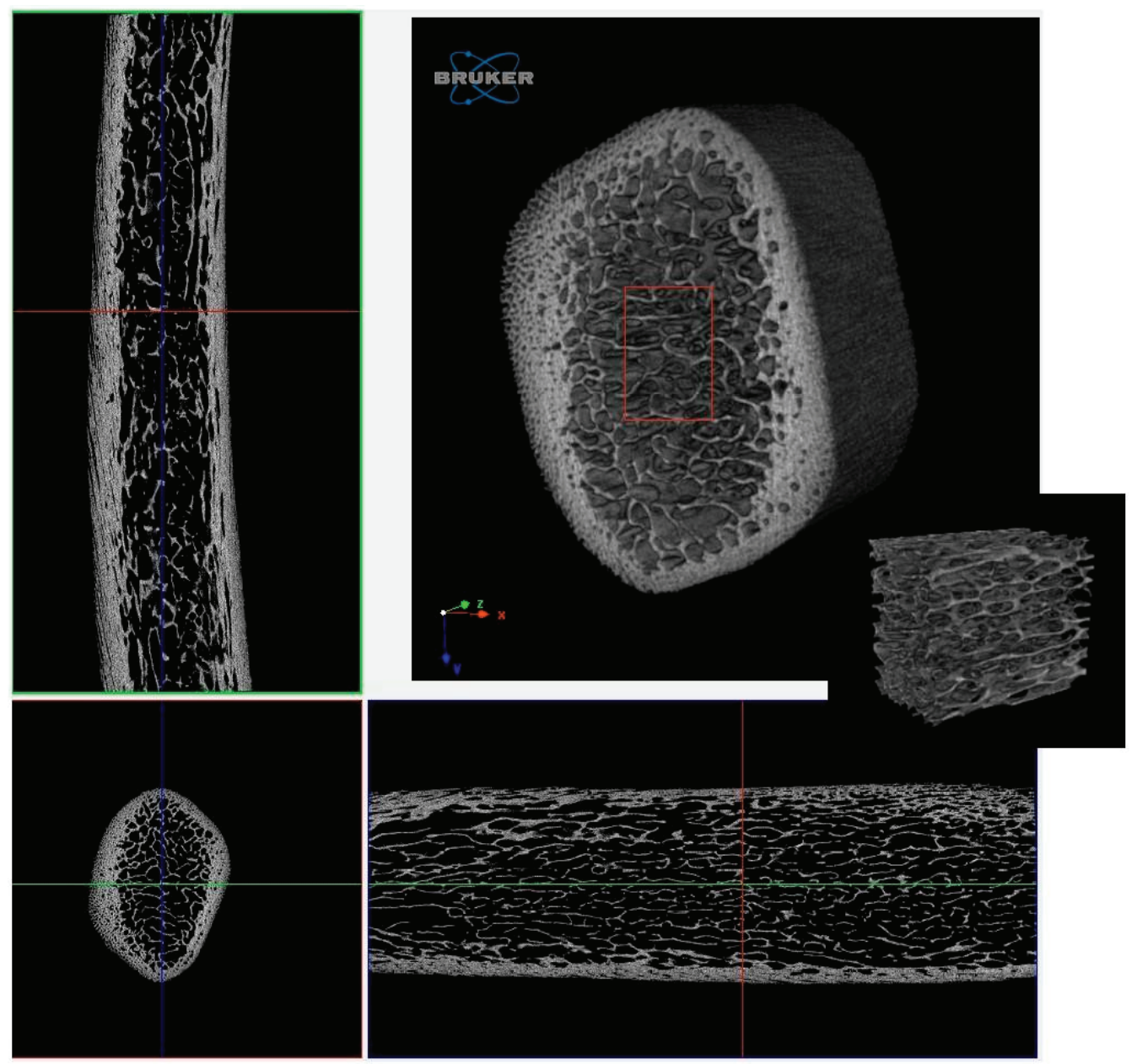

Fig. 1. The cross-section and reconstruction of one of the domestic pig ribs under study; images were obtained using the SkyScan 1172 computed microtomograph, Bruker ${ }^{\mathbb{B}}$ 

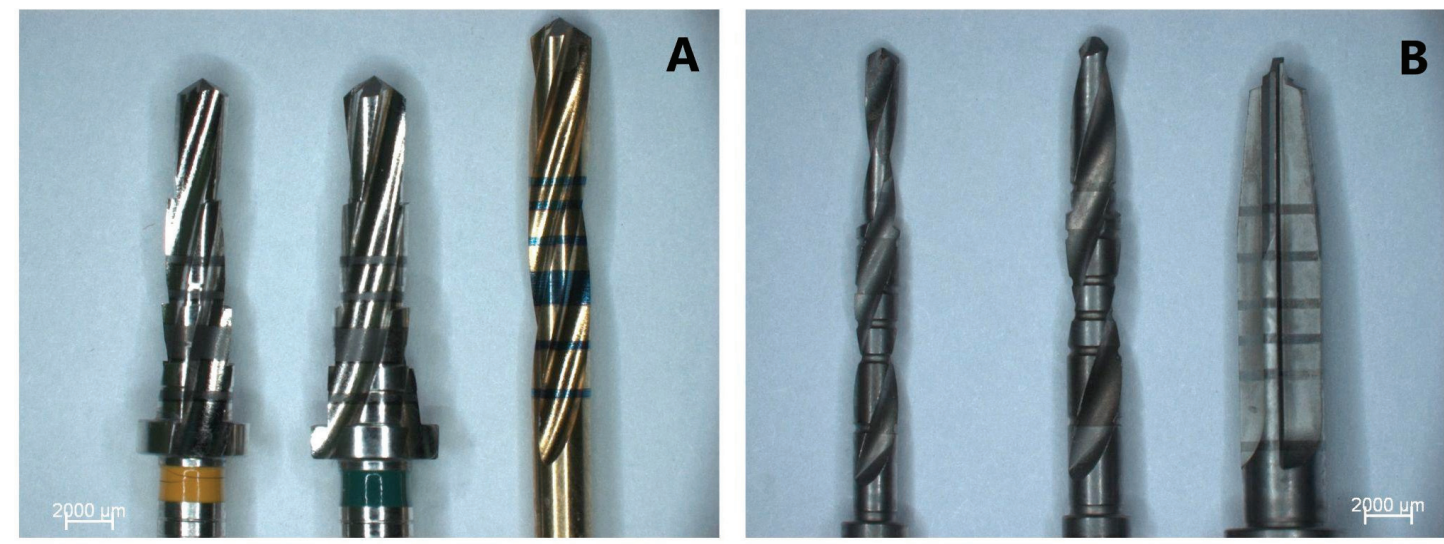

Fig. 2. Drill bits of the systems used during drilling: $A-\operatorname{Hiossen}^{\circledR}$ system and B - Paltop ${ }^{\circledR}$ system

\subsection{Thermography}

The ThermaCAM ${ }^{\circledR}$ P640 (FLIR Systems, Inc., Boston, USA) infrared thermal imaging camera with the spectral range of $7.5-13 \mu \mathrm{m}$ and matrix of 640 $\times 480$ pixels was used for recording temperature changes during drilling. Temperature readings and graphic images were recorded and analysed by the dedicated software (Fig. 3). The measurements were conducted in a closed room without air flow, at various temperatures and ambient conditions. In the presented study, the method of thermographic measurement was based on previous studies that were published in detail in other articles [17], [18].

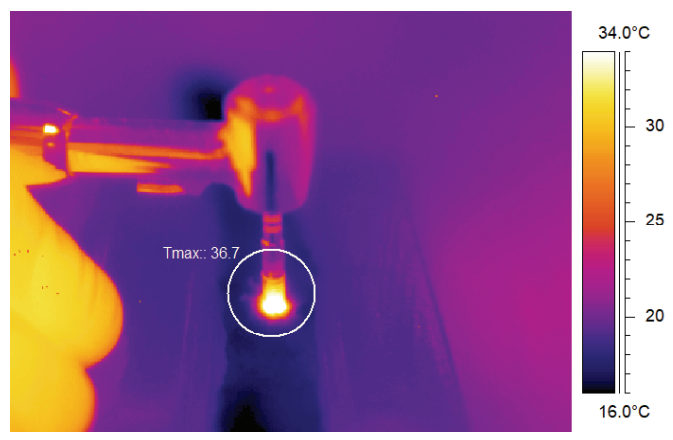

Fig. 3. ThermaCAM ${ }^{\circledR}$ P640 image showing the temperature distribution during the bone preparation

\subsection{The qualitative and quantitative analysis of drilled holes that were cre- ated in the machining process}

After the holes were drilled, each rib was investigated using the high-resolution computed microtomography to analyse the geometry of the machined holes. The SkyScan 1172 computed microtomograph (Bruker ${ }^{\circledR}$,
Kontich, Belgium) was used. Data recording was conducted with a resolution of $12 \mu \mathrm{m}$, with the following tube parameters of $89 \mathrm{kV} / 112 \mathrm{uA}$. An $\mathrm{Al}+\mathrm{Cu}$ filter was used during recording. The exposure time was $2000 \mathrm{~ms}$, the total gantry angle rotation was $180^{\circ}$ and the unit rotation angle was $0.42^{\circ}$. $3 \mathrm{D}$ structural properties were measured using DataViewer and CTAn software. The geometry of the machined holes (diameter, length) and the thickness of the cortical bone tissue layer were determined based on the studies. These parameters were analysed for each hole in two planes - sagittal and frontal. The diameter of the holes was measured in the immediate vicinity of the cortical bone tissue and at the centre of the hole.

\subsection{Statistical analysis}

The statistical analysis was performed using Statistica v13 software (StatSoft, USA) and GraphPad Prism v.9 with the level of statistical significance $\alpha=0.05$. The statistical analysis included the following verifications: (i) verification of the normality of the distribution of the analysed variables and (ii) verification of statistical significance of the differences obtained between three cooling systems. The normality of the distribution of the analysed variables was verified using the Shapiro-Wilk test. Significant differences in terms of the maximum temperatures recorded during drilling with different cooling systems were analysed using the Kruskal-Wallis test.

\section{Results}

The obtained results were divided into three groups according to the cooling system used, i.e., "without 

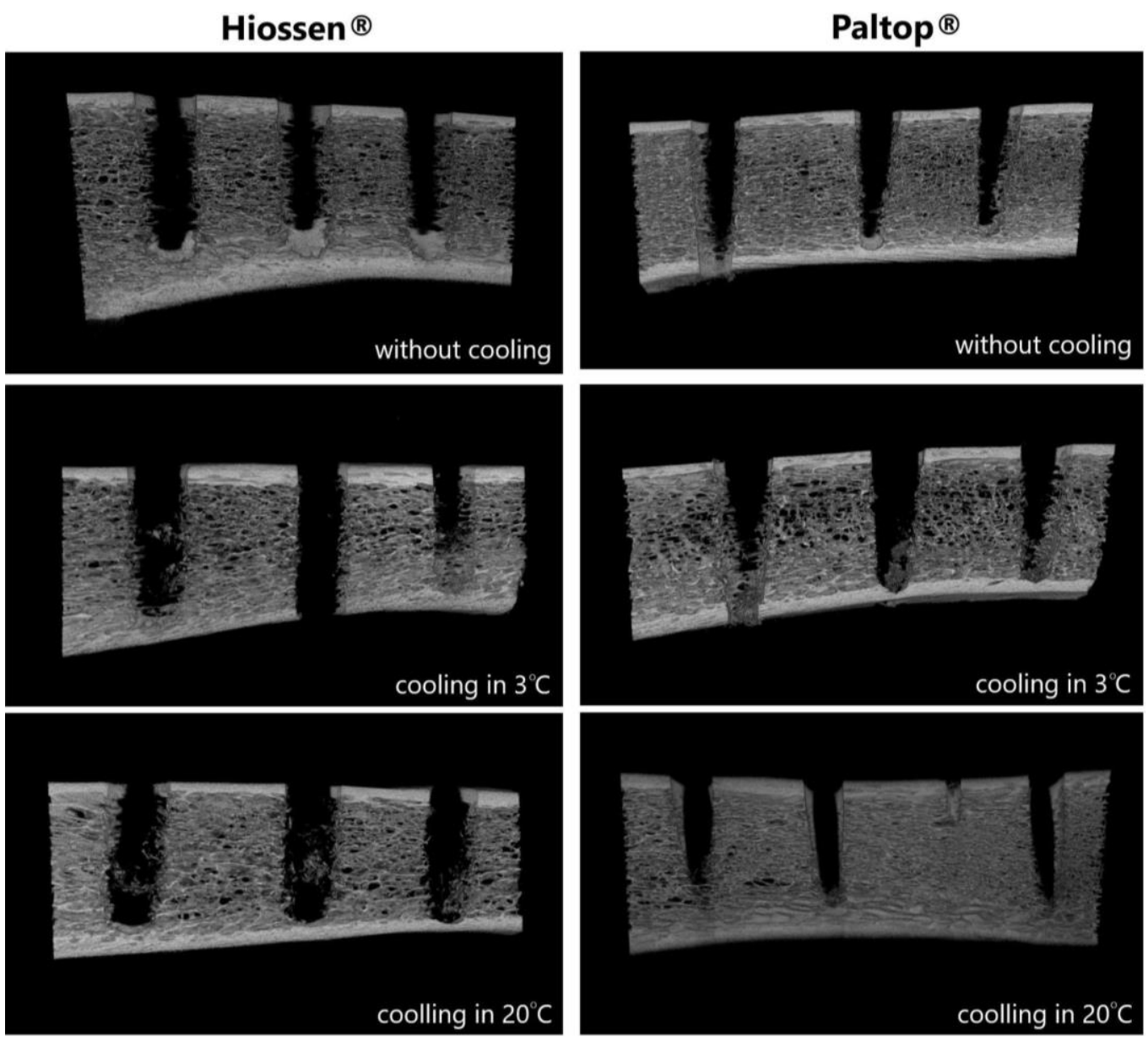

Fig. 4. The comparison of rib holes made using two Hiossen ${ }^{\circledR}$ and Paltop ${ }^{\circledR}$ systems under different cooling conditions: without cooling, cooling at $3{ }^{\circ} \mathrm{C}$, cooling at $20^{\circ} \mathrm{C}$

cooling" - results obtained during machining without using a cooling system, "cooling $3{ }^{\circ} \mathrm{C}$ " - results obtained when using the saline cooling system at $3{ }^{\circ} \mathrm{C}$, "cooling $20{ }^{\circ} \mathrm{C}$ " - results obtained when using the saline cooling system at $20^{\circ} \mathrm{C}$. The results were analysed in two steps. First, the temperatures were compared according to the implant system used (Hiossen ${ }^{\circledR}$,

Table 1. The maximum temperatures obtained during machining with Paltop ${ }^{\circledR}$ drill bits

\begin{tabular}{|c|c|c|c|c|}
\hline \multirow{2}{*}{$\begin{array}{c}\text { Drill bit } \\
\text { diameter } \\
{[\mathrm{mm}]}\end{array}$} & \multirow{2}{*}{$\begin{array}{c}\text { Rotational } \\
\text { speed } \\
{[\mathrm{rpm}]}\end{array}$} & \multicolumn{3}{|c|}{ Maximum temperature $\left[{ }^{\circ} \mathrm{C}\right]$} \\
\hline & & $\begin{array}{l}\text { without } \\
\text { cooling }\end{array}$ & $\begin{array}{l}\text { cooling } \\
\text { at } 3{ }^{\circ} \mathrm{C}\end{array}$ & $\begin{array}{l}\text { cooling } \\
\text { at } 20^{\circ} \mathrm{C}\end{array}$ \\
\hline 2.0 & 800 & 40.5 & 18.8 & 24.0 \\
\hline 2.0 & 1200 & 50.1 & 21.6 & 24.6 \\
\hline 2.0 & 1500 & 54.3 & 22.5 & 24.2 \\
\hline 2.4 & 800 & 30.3 & 17.3 & 25.8 \\
\hline 2.4 & 1200 & 38.5 & 21.9 & 24.0 \\
\hline 2.4 & 1500 & 41.7 & 23.3 & 26.3 \\
\hline 3.75 & 800 & 30.7 & 20.6 & 26.5 \\
\hline 3.75 & 1200 & 34.4 & 20.2 & 25.9 \\
\hline 3.75 & 1500 & 35.3 & 19.8 & 25.3 \\
\hline
\end{tabular}

Paltop $\left.{ }^{\circledR}\right)$, as well as the rotational speed and cooling system used (Tables 1 and 2). Secondly, the geometry of the drilled holes (shape, hole length) was considered in the analysis (Figs. 6 and 7), as well as the thickness of the cortical bone tissue layer (Fig. 5).

Higher temperatures during bone machining were obtained using the Hiossen ${ }^{\circledR}$ system. The obtained tem-

Table 2. The maximum temperatures obtained during machining with Hiossen ${ }^{\circledR}$ drill bits

\begin{tabular}{|c|c|c|c|c|}
\hline \multirow{2}{*}{$\begin{array}{c}\text { Drill bit } \\
\text { diameter } \\
{[\mathrm{mm}]}\end{array}$} & \multirow{2}{*}{$\begin{array}{c}\text { Rotational } \\
\text { speed } \\
{[\mathrm{rpm}]}\end{array}$} & \multicolumn{3}{|c|}{ Maximum temperature $\left[{ }^{\circ} \mathrm{C}\right]$} \\
\hline & & $\begin{array}{l}\text { without } \\
\text { cooling }\end{array}$ & $\begin{array}{l}\text { cooling } \\
\text { at } 3^{\circ} \mathrm{C}\end{array}$ & $\begin{array}{l}\text { cooling } \\
\text { at } 20^{\circ} \mathrm{C}\end{array}$ \\
\hline 2.8 & 800 & 52.2 & 24.4 & 25.1 \\
\hline 2.8 & 1200 & 53.9 & 25.3 & 25.6 \\
\hline 2.8 & 1500 & 55.1 & 25.1 & 26.3 \\
\hline 3.5 & 800 & 37.5 & 21.1 & 26.0 \\
\hline 3.5 & 1200 & 39.2 & 30.3 & 26.6 \\
\hline 3.5 & 1500 & 40.4 & 21.1 & 27.3 \\
\hline 4.0 & 800 & 31.9 & 20.9 & 25.3 \\
\hline 4.0 & 1200 & 33.5 & 22.9 & 24.6 \\
\hline 4.0 & 1500 & 34.8 & 20.9 & 25.2 \\
\hline
\end{tabular}


peratures were higher compared to those obtained for the Paltop ${ }^{\circledR}$ system, both in the case of dry drilling and in the cases where cooling systems were used. The highest temperatures $\left(31.9^{\circ} \mathrm{C}-55.1^{\circ} \mathrm{C}\right)$ were obtained for the "without cooling" group (drill bit diameter of $2.8 \mathrm{~mm}$ ), with the maximum temperature, $55.1{ }^{\circ} \mathrm{C}$, obtained at $1500 \mathrm{rpm}$. For the Paltop ${ }^{\circledR}$ system, the resulting temperatures range from $30.3{ }^{\circ} \mathrm{C}$ to $54.3^{\circ} \mathrm{C}$. The temperature of $54.3{ }^{\circ} \mathrm{C}$ was also obtained at $1500 \mathrm{rpm}$. For preparation without cooling for the Hiossen ${ }^{\circledR}$ sys- tem, the cortical bone layer thickness was $1.00 \mathrm{~mm}$ (median) and the hole length was $11 \mathrm{~mm}$ (median). For the Paltop ${ }^{\circledR}$ system, these parameters were lower and were $0.72 \mathrm{~mm}$ (thickness of the cortical bone layer) and $9.31 \mathrm{~mm}$ (length of the drilled hole).

Lower temperatures were obtained during drilling with a cooling system. These temperatures ranged from $18.8^{\circ} \mathrm{C}$ to $26.5^{\circ} \mathrm{C}$ for the Paltop ${ }^{\circledR}$ system and from $20.9{ }^{\circ} \mathrm{C}$ to $30.3{ }^{\circ} \mathrm{C}$ for the Hiossen ${ }^{\circledR}$ system. For the Paltop ${ }^{\circledR}$ system, the obtained temperatures
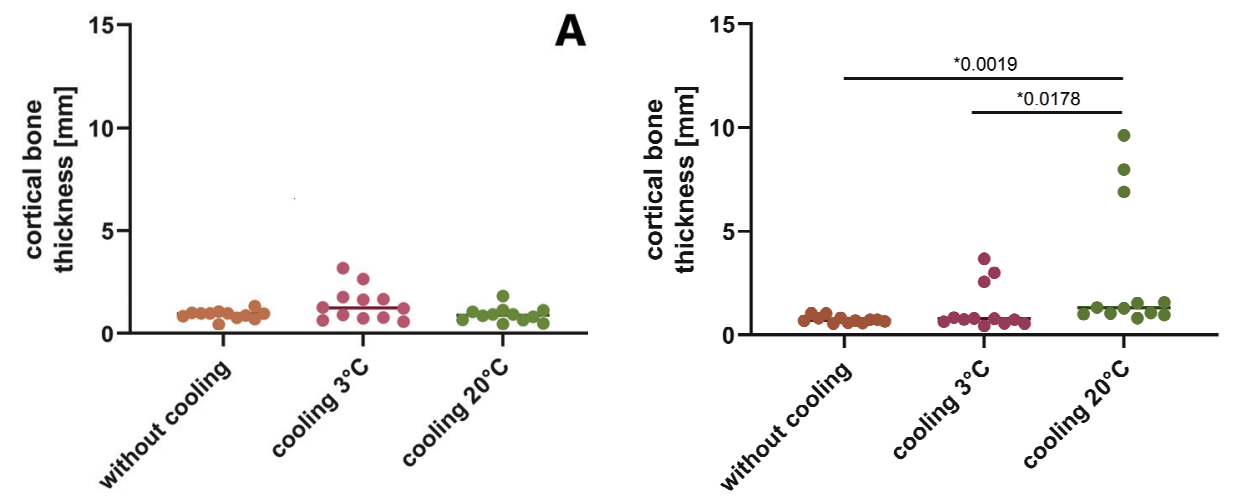

Fig. 5. The thickness of the cortical bone tissue layer during machining with $\mathrm{A}-\mathrm{Hiossen}^{\circledR}$ and $\mathrm{B}-\mathrm{Paltop}^{\circledR}$ drill bits. The horizontal line shows the median
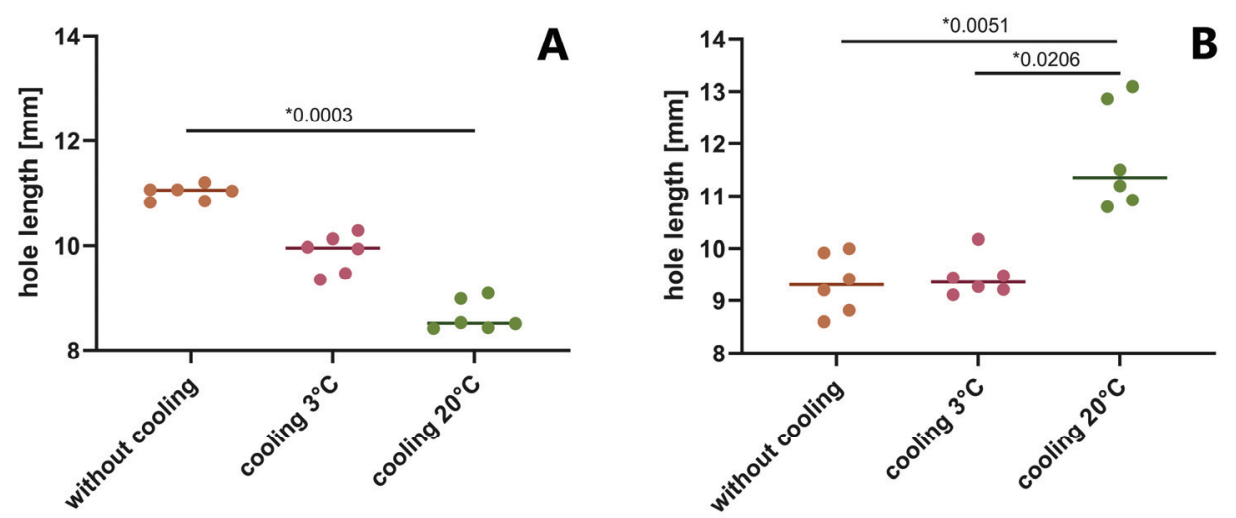

Fig. 6. The length of the hole made with $\mathrm{A}-\operatorname{Hiossen}^{\circledR}$ and $\mathrm{B}-$ Paltop $^{\circledR}$ drill bits. The horizontal line shows the median
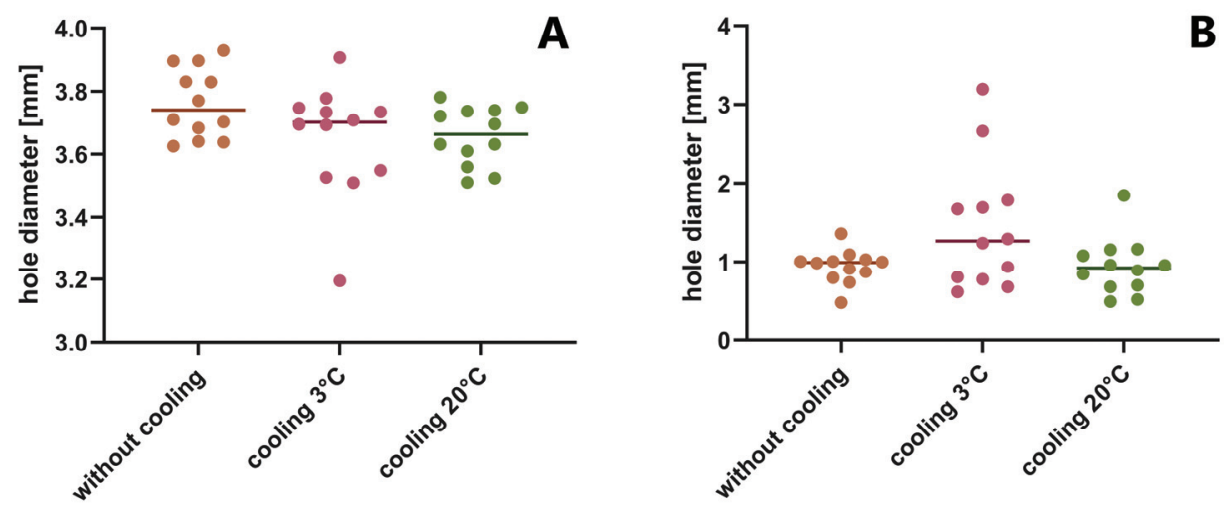

Fig. 7. The diameter of the hole made with $A-\operatorname{Hiossen}^{\circledR}$ and $B-$ Paltop $^{\circledR}$ drill bits. The horizontal line shows the median 

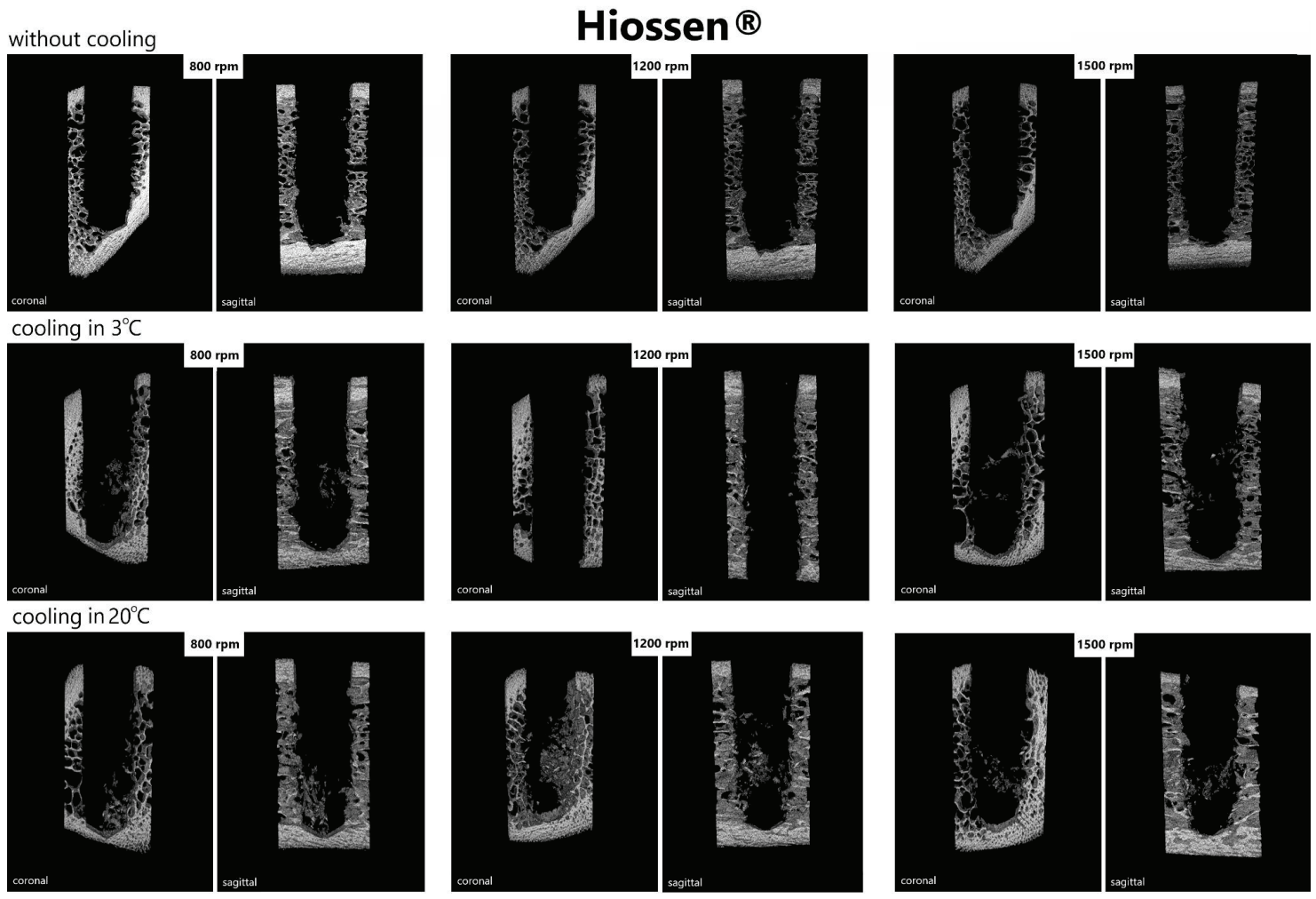

Fig. 8. The comparison of individual drilled holes and bone around the hole in the frontal and sagittal planes.

The holes were made using two Hiossen ${ }^{\circledR}$ systems under different cooling conditions - without cooling, cooling at $3{ }^{\circ} \mathrm{C}$ and cooling at $20^{\circ} \mathrm{C}$ - and with different rotational speeds such as $800 \mathrm{rpm}, 1200 \mathrm{rpm}$ and $1500 \mathrm{rpm}$
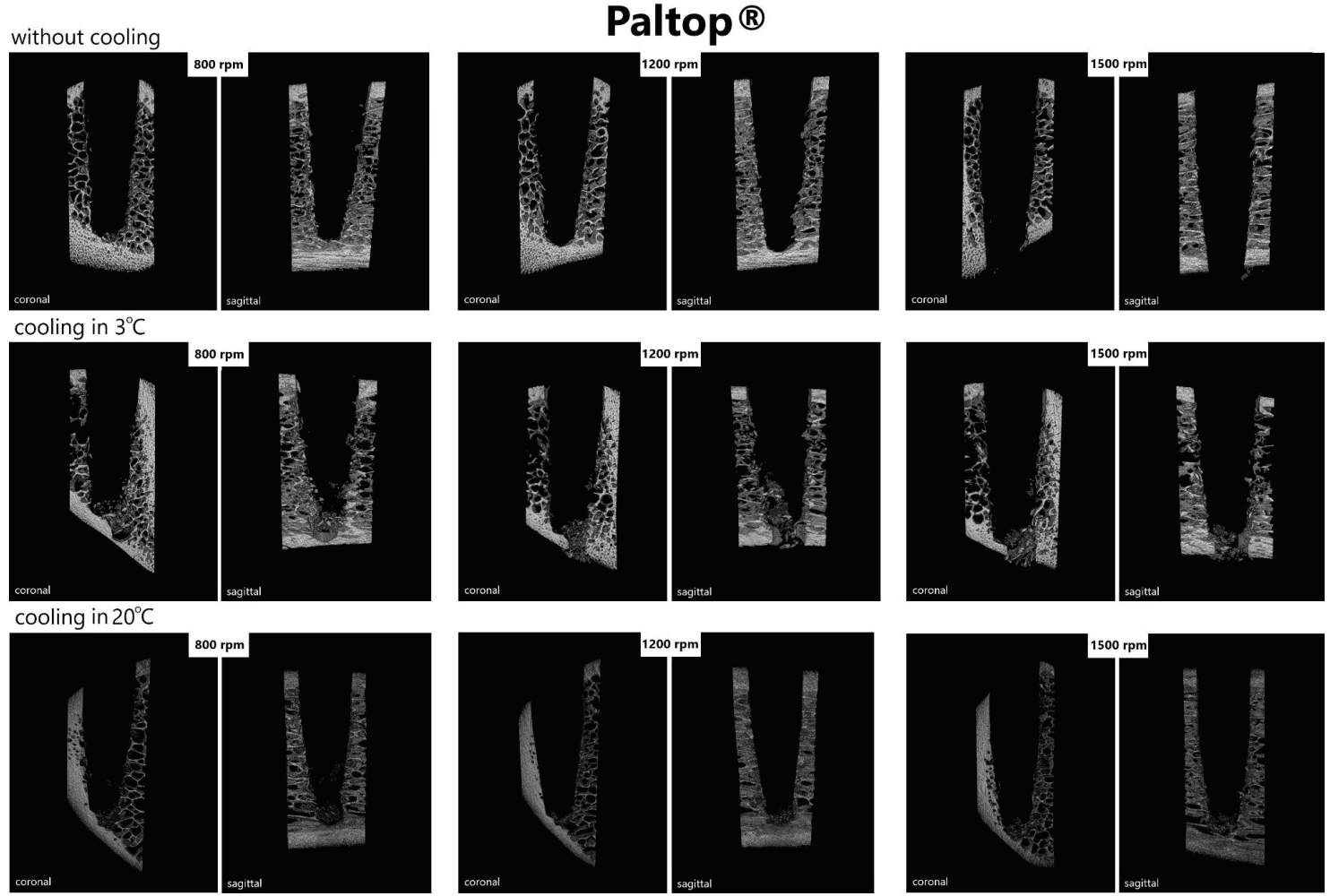

Fig. 9. The comparison of individual drilled holes and bone around the hole in the frontal and sagittal planes.

The holes were made using two Paltop ${ }^{\circledR}$ systems under different cooling conditions - without cooling, cooling at $3{ }^{\circ} \mathrm{C}$ and cooling at $20^{\circ} \mathrm{C}$ - and with different rotational speeds such as $800 \mathrm{rpm}, 1200 \mathrm{rpm}$ and $1500 \mathrm{rpm}$ 
varied with the cooling medium temperature and they were lower (regardless of the machining speed used) when a saline solution at $3{ }^{\circ} \mathrm{C}$ is used. The differences between the "cooling $3{ }^{\circ} \mathrm{C}$ " and "cooling $20{ }^{\circ} \mathrm{C}$ " groups were $26 \%$ for $800 \mathrm{rpm}, 22 \%$ for $1200 \mathrm{rpm}$ and $13 \%$ for $1500 \mathrm{rpm}$. For the Hiossen ${ }^{\circledR}$ system, the differences obtained between these groups were lower $-12 \%$, $3 \%$ and $13 \%$, respectively. For the "cooling $3{ }^{\circ} \mathrm{C}$ " group, the temperatures obtained during machining are $22.1{ }^{\circ} \mathrm{C}$ (for $800 \mathrm{rpm}$ ), $26.2{ }^{\circ} \mathrm{C}$ (for $1200 \mathrm{rpm}$ ) and $22.4{ }^{\circ} \mathrm{C}$ (for $1500 \mathrm{rpm}$ ). For cooling with the saline solution at room temperature ("cooling $20{ }^{\circ} \mathrm{C}$ " group), temperatures were similar $-25.5^{\circ} \mathrm{C}, 25.6^{\circ} \mathrm{C}$ and $26.3{ }^{\circ} \mathrm{C}$, respectively. It should be noted, however, that for the preparation using saline at $3{ }^{\circ} \mathrm{C}$ (the "cooling3 ${ }^{\circ} \mathrm{C}$ " group), the thickness of the cortical bone layer was $1.27 \mathrm{~mm}$ (median) and the length of the drilled hole was $9.96 \mathrm{~mm}$ (median), whereas for this solution at room temperature (the "cooling $20{ }^{\circ} \mathrm{C}$ " group) these values were significantly lower $-0.92 \mathrm{~mm}$ and $8.52 \mathrm{~mm}$, respectively. For the Paltop ${ }^{\circledR}$ system, the temperatures obtained when cooling with saline at room temperature had higher values compared to those obtained when cooling with this solution at $3{ }^{\circ} \mathrm{C}$. These differences were $26 \%$ for $800 \mathrm{rpm}$ and $13 \%$ for $1500 \mathrm{rpm}$. It should be noted, however, that in that case the holes were drilled entirely through the cortical bone layer.

In the next step, the diameter of the drilled holes was analysed (Fig. 7). For both the Paltop ${ }^{\mathbb{B}}$ and Hiossen ${ }^{\circledR}$ systems, the smallest differences between the expected hole diameter, understood as the drill bit diameter, and the diameter of the drilled hole were found in the "without cooling" group. For the Hiossen ${ }^{\circledR}$ system, these differences were approximately $12 \%$ and they were obtained at $800 \mathrm{rpm}$, while for the Paltop ${ }^{\circledR}$ system they are $20 \%$ (at $1500 \mathrm{rpm}$ ). It should be noted that for the Paltop ${ }^{\circledR}$ system, the bone tissue had a thicker cortical layer. In the case of preparation with cooling systems, there were larger differences between the aforemen- tioned diameters $-17 \%$ for the Hiossen ${ }^{\circledR}$ system and $23 \%$ for the Paltop ${ }^{\circledR}$ system. In each case, the differences between the measurement groups are not statistically significant $(\alpha=0.05)$.

\section{Discussion}

The present study is the analysis of the temperature generated during the bone tissue machining. The existing studies in this field are related only to the impact of the parameters of the machining process (rotational speed, drill bit diameter) on the amount of heat generated. No study presented so far has considered the structure of the bone tissue as well as the geometry of the holes made. Thus, this article presents a comprehensive approach to the subject; the analysis included both parameters of the machining process (rotational speed, cooling method), the geometry of the drill bits used, as well as the thickness of the cortical bone layer and the geometry of the holes made.

In this study, drill bits of two implant dental systems were used - Paltop ${ }^{\circledR}$ and Hiossen ${ }^{\circledR}$. The macroscopic analysis revealed that these drill bits have similar geometry (point angle) (Table 1, Fig. 2), however, their diameters vary (Table 2). The conducted analysis proved that larger diameter drill bits (Hiossen ${ }^{\circledR}$ drill bits) generate more heat during the machining process, as evidenced by higher temperatures obtained for the Hiossen system in each case. The drill bits used in this case have larger diameters compared to the Paltop ${ }^{\circledR}$ system $-2.8 \mathrm{~mm}, 3.5 \mathrm{~mm}, 4 \mathrm{~mm}$. The diameters of the Paltop $^{\circledR}$ drill bits are $2.0 \mathrm{~mm}, 2.4 \mathrm{~mm}, 3.75 \mathrm{~mm}$. These results do not confirm the results of the analyses conducted by Flangan [10] and Marković [19], according to which an increase in the drill bit diameter reduces the amount of heat generated during the machining of bone tissue. It should be noted that the
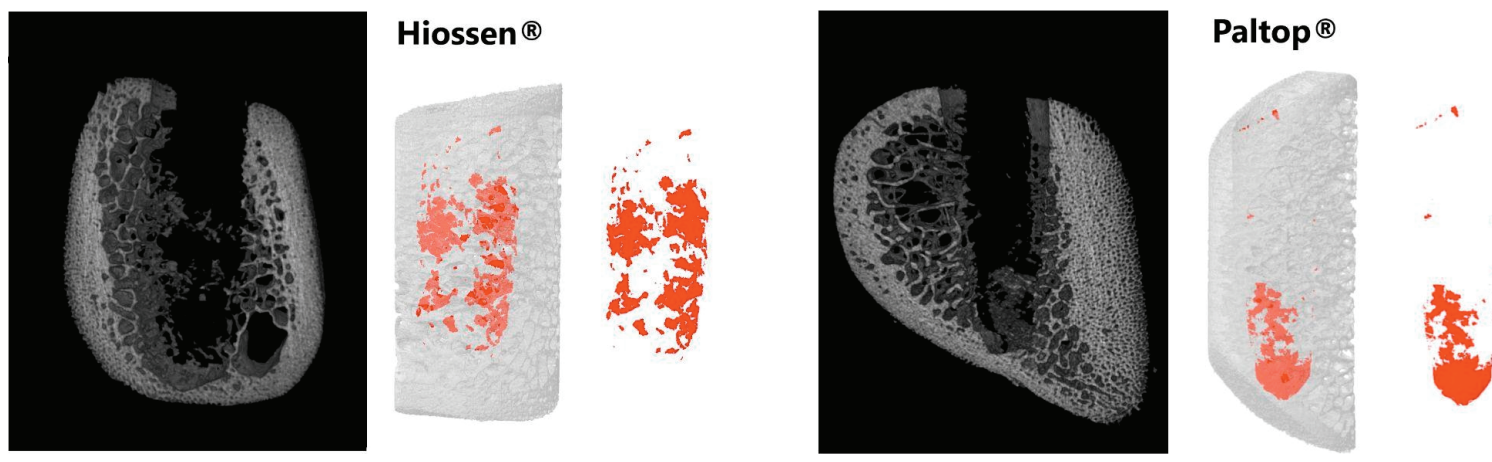

Fig. 10. The comparison of two sample holes with a chip formed during the A - Hiossen ${ }^{\circledR}$ system drilling process (cooling at $3{ }^{\circ} \mathrm{C}$, rotational speed of the drill bit at $1500 \mathrm{rpm}$ ) and B - Paltop ${ }^{\circledR}$ system drilling process (cooling at $20^{\circ} \mathrm{C}$, rotational speed at $1500 \mathrm{rpm}$ ) 
structural analysis using high-resolution computed microtomography revealed the presence of chips in the holes made with the Paltop ${ }^{\mathbb{R}}$ drill bits, which may indicate that heat dissipation from the area under machining is impeded and this is typical of machining of engineering materials. However, the hypothesis in question was not confirmed by the obtained results of the presented study. Despite the impeded chip evacuation in the case of machining with the Paltop ${ }^{\circledR}$ drill bits and the resulting disturbed heat balance, higher temperatures were obtained in the case of machining with the Hiossen ${ }^{\circledR}$ drill bits (Table 2).

The results also show a significant effect of the applied rotational speed on the amount of heat generated, i.e., the amount of heat increases as the rotational speed increases (Tables 1 and 2). For both the Hiossen ${ }^{\mathbb{B}}$ and Paltop ${ }^{\mathbb{B}}$ systems, temperatures obtained at $1500 \mathrm{rpm}$ have the highest values $\left(55.1^{\circ} \mathrm{C}\right.$ for the Hiossen ${ }^{\circledR}$ system and $54.3^{\circ} \mathrm{C}$ for the Paltop ${ }^{\circledR}$ system). The obtained results are consistent with those presented by Nam et al. [21], Augustin et al. [2] and Kaldindi [15], according to which the amount of generated heat increases with increasing drill bit diameter and rotational speed. However, these results contradict those presented by Sharawy et al. [24], who observed that the temperature generated during machining at $2500 \mathrm{rpm}$ is lower compared to the temperature generated during machining at $1667 \mathrm{rpm}$. According to the authors, these differences are due to the time that is required for making holes of a given length (in the studies conducted by the authors, the hole length was fixed at $8 \mathrm{~mm}$ ). The results obtained in the present study do not confirm this relationship, which will be discussed in the next section. Nevertheless, it should be emphasised that the drilled holes do not have the same length.

According to the analysis conducted in the presented study, the amount of heat generated during machining is also a consequence of the cooling system used. The obtained results clearly reveal that the use of cooling system reduces the amount of heat generated during the preparation, which is evidenced by the lower temperatures obtained in this case compared to the temperatures obtained in the case of machining without the cooling system. This proves previous literature reports [15]. These results partly confirm the results obtained by Mecran et al. [20], according to which the amount of generated heat is also affected by the temperature of the cooling medium used. In the cases (for the Hiossen ${ }^{\circledR}$ system) in which there were no statistically significant differences between both the thickness of the cortical bone tissue (Fig. 5A) and the length of the drilled holes (Fig. 6A), the amount of heat generated when using saline at room temperature is greater compared to the amount of heat generated when using this solution at $4{ }^{\circ} \mathrm{C}$. The use of different coolant temperatures did not affect the amount of heat generated for different thicknesses of the cortical bone layer under study, as was obtained for the Paltop ${ }^{\circledR}$ system (Fig. 5B). The relationship between the temperature generated during the preparation and the depth of the drilled holes/coolant temperature was statistically significant for both systems (Figs. 5 and 6). This indicates a significant impact of the hole length on the amount of heat generated in the machining process - the greater the hole length, the greater amount of heat generated during machining. The results obtained for the Paltop ${ }^{\circledR}$ system also show a significant impact of the thickness of the cortical bone layer on the amount of heat generated - the amount of heat increases with increasing thickness. According to Eriksson et al. [7], [8], this is related to the internal structure of the cortical bone tissue. This tissue has higher stiffness compared to cancellous tissue, which results in the need for higher pressure and higher friction during machining. Moreover, due to the low porosity of cortical bone tissue, the energy generated during the machining process is not dissipated (as is the case of cancellous tissue machining - due to high porosity of this tissue and filling of pores with bone marrow and blood vessels). Specific mechanical parameters, i.e., increased bone density and hardness in the cortical layer, are used in bicortical implantation [13]. It should also be noted that the obtained results revealed that the use of a cooling system in the form of a saline solution at a certain temperature does not affect the accuracy of the drilled hole. The differences between the drill bit diameter and the diameter of the drilled hole for machining without a cooling system and with saline cooling are not statistically significant $(\alpha=0.05)$.

\section{Conclusions}

The results obtained in this study revealed a significant effect of rotational speed, drill bit diameter and type of cooling system on the amount of heat generated during bone preparation. These results partially support previous literature reports. An increase in both the drill bit diameter and in the rotational speed increases the amount of heat generated. This study found that the thickness of the cortical bone layer is also a significant factor that affects the amount of heat generated (Fig. 5). Due to the compact 
structure of this tissue, its high stiffness and the absence of pores and blood vessels in its structure, the drilling process requires a lot of pressure, and the energy generated during machining is entirely converted into heat. According to the obtained results, the temperature generated during preparation may be reduced by using a coolant (at low temperature), which reduces the risk of negative effects of heat on bone tissue cells and on thermal necrosis [27]. The observed relationships are of great importance for understanding the process of thermal energy dissipation in bone tissue, giving the opportunity to consider them in clinical settings. This is essential for controlling the tissue cooling process, ensuring optimal parameters - this has a direct effect on osseointegration.

\section{Acknowledgments}

The authors acknowledge Katarzyna Fita, PhD, from Department of Pediatric Dentistry and Preclinical Dentistry, Wroclaw Medical University, Karol Kirstein and Professor Aleksander Chroszcz from Department of Biostructure and Animal Physiology, Wroclaw University of Environmental and Life Sciences. The study was supported by statutory research and development activity funds assigned to the Faculty of Veterinary Medicine, Wroclaw University of Environmental and Life Sciences.

\section{Conflicts of interest}

The authors declare no conflict of interest.

\section{References}

[1] Alwan A., The effect of heat on osseointegration in two steps dental implant, EJPMR, 2017, 4 (6), 126-127.

[2] Augustin G., Davila S., Mihoci K., Udiljak T., Vedrina D.S., ANTABAK A., Thermal osteonecrosis and bone drilling parameters revisited, Arch. Orthop. Trauma Surg., 2008, 128, 71-77.

[3] Benington I.C., Biagioni P.A., Briggs J., Sheridan S., LAMEY P.J., Thermal changes observed at implant sites during internal and external irrigation, Clin. Oral Implants Res., 2002, 13, 293-297.

[4] BRISMAN D.L., The effect of speed, pressure, and time on bone temperature during the drilling of implant sites, Int. J. Oral Maxillofac. Implants, 1996, 11, 35-37.

[5] Chacon G.E., Bower D.L., Larsen P.E., McGlumphy E.A., BECK F.M., Heat production by 3 implant drill systems after repeated drilling and sterilization, J. Oral Maxillofac. Surg., 2006, 64 (2), 265-269.

[6] Carvalho A.C., Queiroz T.P., OKamoto R., Margonar R., Garcia I.R., JR, MAGro Filho O., Evaluation of bone heating, immediate bone cell viability, and wear of high-resistance drills after the creation of implant osteotomies in rabbit tibias, Int. J. Oral Maxillofac. Implants, 2011, 26, 1193-1201.
[7] Eriksson R.A., Albrektsson T., Magnusson B., Assessment of bone viability after heat trauma. A histological, histochemical and vital microscopic study in the rabbit, Scand. J. Plast. Reconstr. Surg., 1984, 18, 261-268.

[8] Eriksson A., Albrektsson T., Grane B., McQueen D., Thermal injury to bone. A vital-microscopic description of heat effects, Int. J. Oral Surg., 1982, 11, 115-121.

[9] Feine J.S., Carlsson G.E., Awad M.A., Chehade A., Duncan W.J., Gizani S., Head T., Heydecke G., Lund J.P., Macentee M., Mericske-Stern R., Mojon P., Morais J.A., Naert I., Payne A.G.T., Penrod J., Stoker G.T., Tawse-Smith A., TAYlor T.D., Thomason J.M., Thomson W.M., WISMEIJER D., The McGill consensus statement on overdentures. Mandibular two-implant overdentures as first choice standard of care for edentulous patients, Montreal, Quebec, Int. J. Oral Maxillofac. Implants, 2002, 17 (4), 601-602.

[10] Flanagan D., Osteotomy irrigation: Is it necessary?, Implant Dent., 2010, 19, 241-249.

[11] Gil J.J., DíAz I., Accini F., Inferring Material Properties in Robotic Bone Drilling Processes, Acta Bioeng. Biomech., 2019, 21 (3), 109-111.

[12] GŁowacki J., Tomanik M., Pezowicz C., Krauss H., Mechanical and histomorphometrical evaluation of false and floating ribs of young adults with idiopathic scoliosis, Acta Bioeng. Biomech., 2020, 22 (2), 3-10.

[13] Ihde S., Patka Ł., JaneczeK M., Kosior P., KiryK J., DoBrZYŃski M., Bite Reconstruction in the Aesthetic Zone Using One-Piece Bicortical Screw Implants, Case Rep. Dent., 2018, 29, 4671482.

[14] JASTRZĘBSKI D., PERZ R., Rib kinematics analysis in oblique and lateral impact tests, Acta Bioeng. Biomech., 2020, 22 (1), 1-9.

[15] Kalidindi V., Optimization of Drill Design and Coolant Systems during Dental Implant Surgery, Master's Thesis, University of Kentucky, Lexington, KY, USA, 2004.

[16] KIM S.J., Yoo J., KIM Y.S., SHIN S.W., Temperature change in pig rib bone during implant site preparation by low-speed drilling, J. Oral Maxillofac. Surg., 2010, 5, 522-527.

[17] Kirstein K., Horochowska M., Jagiello J., BubaK J., Chrószcz A., Kuropka P., DobrzyŃSKi M., PORADOWSKi D., Michalek M., Borawski W., JaneczeK M., Dental Implant Site Drilling and Induced Morphological Changes Correlated with Temperature in Pig's Rib Used as the Human Jaw Model, Appl. Sci., 2021, 11, 2493, 1-11.

[18] Kirstein K., Dobrzynski M., Kosior P., Chrószcz A., Dudek K., Fita K., Parulska O., Rybak Z., Skalec A., SzKLARZ Sz., JANECZEK M., Infrared Thermographic Assessment of Cooling Effectiveness in Selected Dental Implant Systems, BioMed Research International, 2016, Article ID 1879468, DOI: $10.1155 / 2016 / 1879468$.

[19] Markovic A., Mišıć T., Milicic B., CAlvo-Guirado J.L., AlEKSIĆ Z., ĐinIĆ A., Heat generation during implant placement in low-density bone: Effect of surgical technique, insertion torque and implant macro design, Clin. Oral Implants Res., 2013, 24, 798-805.

[20] Mercan U., Sumer M., Kaya O.A., Keskiner I., Meral D.G., ERDOGAN O., An In-vitro study on thermal changes during implant drilling with different irrigation volumes, Niger J. Clin. Pract., 2019, 22, 350-354.

[21] Nam O., Yu W., ChOI M.Y., KyUnG H.M., Monitoring of bone temperature during osseous preparation for orthodontic micro-screw implants: Effect of motor speed and pressure, Key Eng. Mater, 2006, 321-322, 1044-1047. 
[22] OH H.J., Wikesjo U.M., Kang H.S., Ku Y., EOM T.G., Koo K.T., Effect of implant drill characteristics on heat generation in osteotomy sites: a pilot study, Clin. Oral Implants Res., 2011, 22, 722-726.

[23] Scarano A., Piattelli A., Assenza B.,Carinci F., DI DONATO L., ROMANI G.L., MERLA A., Infrared thermographic evaluation of temperature modifications induced during implant site preparation with cylindrical versus conical drills, Clin. Implant Dent. Relat. Res., 2011, 13, 319-323.

[24] Sharawy M., Misch C.E., Weller N., Tehemar S., Heat Generation during Implant Drilling: The Significance of Motor Speed, J. Oral Maxillofac. Surg., 2002, 60, 1160-1169.
[25] Sener B.C., Dergin G., Gursoy B., Kelesoglu E., Slih I., Effects of irrigation temperature on heat control in vitro at different drilling depths, Clin. Oral Implants Res., 2009, 20, 294-298.

[26] Sumer M., Misir A.F., Telcioglu N.T., Guler A.U., YENISEY M., Comparison of heat generation during implant drilling using stainless steel and ceramic drills, J. Oral Maxillofac. Surg., 2011, 69, 1350-1354.

[27] Trisi P., Berardini M., Falco A., VulPiani M.P., Effect of Temperature on the Dental Implant Osseointegration Development in Low-Density Bone: An In Vivo Histological Evaluation, Implant Dent., 2015, 24 (1), 96-100. 